\title{
Shawls and Sable Furs: How to Be a Boyar under the Phanariot Regime (1710-1821)
}

\begin{abstract}
Wallachia and Moldavia, as peripheries of the Ottoman Empire, were ruled by Phanariot princes throughout the eighteenth century. These "Greeks" were dragomans at the sultan's court or high dignitaries of the Greek Orthodox Patriarchate in Constantinople and governed the two Danubian Principalities in the name of the sultan. My article examines how the local nobility, the Orthodox elite of the countries, reacted and adapted to the Oriental ways of the Phanariot courts. It reveals how the local elites adhered to the Phanariot political regimes and tacitly adopted the new fashions and lifestyles, which would eventually be instrumental in the fashioning of their identity. The available primary sources consist of dowry lists, probate inventories, sumptuary laws, and visual documents (engravings and prints published in travelogues, paintings, and costume books), and they show in great detail the process of self-fashioning and self-display through clothes and costumes.
\end{abstract}

After the Ottoman advance on Vienna in the late seventeenth century, the Christian elites of Central and Southeastern Europe embarked on a game of appearances using Ottoman fashion as a model. Ottoman cultural influence was visible in the two principalities of Moldavia and Wallachia already in the seventeenth century, but it became more dominant after 1711, when the Ottoman grip on the region tightened. Until that year, members of the local nobility, the boyars, had had the right to choose native-born rulers from amongst their own political elite. But after the battle of Stănileşti by the River Prut in 1711 and the self-imposed Russian exile of the prince of Moldavia, Dimitrie Cantemir, the rulers of the Danubian principalities were directly appointed by the sultan, selected from among the dragomans or high officials of the Orthodox Patriarchy of Constantinople residing in the Phanar district of Istanbul. ${ }^{1}$ Known

1 My special thanks for the English translation of this study are addressed to Dr. James Christian Brown (University of Bucharest). This study was supported by the project Luxury, Fashion and Social Status in Early Modern South-Eastern Europe (LuxFaSS), with number ERC2014-CoG no. 646489, financed by the European Research Council and hosted by New Europe College, Bucharest. I would like to thank Denise Klein, Cornelia Aust, Thomas Weller for their insightful reading of earlier drafts of this paper. I am also grateful to Costina Anghel, curator of the National Museum of Art in Bucharest, who has always helped me find me way in the 
as Phanariots, these new rulers arrived in the Romanian lands with a host of other "Greeks" from the imperial capital, and they transformed the princely courts of Bucharest and Iaşi according to their tastes.

Along with the princely courts, local society, too, became more and more Ottomanized. The native elite rapidly imitated the new fashion of the Phanariots ${ }^{2}$ and, in most cases, adopted also the original Greek and Ottoman names together with the objects. ${ }^{3}$ Dowry lists, wills, tax assessments, probate inventories, and votive portraits in churches reflect this Ottomanization of the local elites' fashion. Anton Maria del Chiro, the Italian secretary of Prince Constantine Brâncoveanu (r. 1688-1714) and Prince Stephen Cantacuzino (r. 1714-1716), describes a Wallachian society adept at copying Ottoman models in the fields of fashion, manners, and culinary tastes. ${ }^{4}$ Indeed, the upper levels, at least, of Romanian society seem to have been Ottomanized. However, the boyars did not borrow only from the Ottomans; they also followed other models provided by their Christian religion and heritage and by their connections to Eastern and Western Europe.

This article investigates how "Ottoman" the Romanian boyars were during this period of multiple affiliations, between 1710 and 1821, by analyzing the ways in which they dressed. I begin with a brief outline of the ambivalent status of the boyars at the Phanariot court and then focus on certain clothing items, such as the boyars' special headgear, shawls, and furs, as symbols of their Ottomanization and as means of social distinction. The discussion shows, for example, how the işlic hat turned from a costume accessory into a political instrument that was used in the internal competition for precedence on the political stage. The second part of the article discusses the Phanariots' reaction to the local elite's ostentatious display of luxury and its practices of social distinction, based in particular on a study of sumptuary laws.

museum collections. After the fall of Constatinople in 1453, many Orthodox Christians settled in the Phanar district. On this topic see Christine Philliou: Biography of an Empire. Governing Ottomans in an Age of Revolution. Berkeley 2011.

2 Adam Jasienski: A Savage Magnificence. Ottomanizing Fashion and the Politic of Display in Early Modern East-Central Europe, in: Muqarnas 31 (2014), 174-176; Michał Wasiucionek: Conceptualizing Moldavian Ottomanness. Elite Culture and Ottomanization of the SeventeenthCentury Moldavian Boyars, in: Medieval and Early Modern Studies for Central and Eastern Europe 8 (2016), 39-78.

3 Ştefan Greceanu: Viaţa lui Constantin vodă Brâncoveanul. Bucharest 1906, 278-313.

4 Anton Maria del Chiaro: Istoria delle Moderne Rivoluzioni della Valachia. Venice 1718. 


\section{Boyars and the Princely Court}

Only boyars who belonged to the upper class of the evgheniţi ${ }^{5}$ and held important office had access to the Phanariot court and, thus, by extension to the cultural model mentioned above. These so-called "great boyars" were the descendants of old families with considerable wealth, which gave them access to high office. To appear at the princely court and participate actively in court life, they also had to acquire a certain etiquette. The "petty boyars", by contrast, did not have access to the court. They were one level lower in the social hierarchy and did not have the financial means necessary to gain positions in the princely council; they had to content themselves with lesser posts in the secondary administrative apparatus, even if they came from old families. ${ }^{6}$

Even though the great boyars saw in the princely court a source of power and income and a model style of life, they considered themselves superior to the Phanariots and the people they brought with them from Istanbul. They were proud of their long ancestry and tried under all circumstances to affirm the priority they believed it granted them. Luxury and fashion were important means for the local elites to display their claim to precedence as well as their political opposition. Indeed, the boyars used shawls, furs, robes, and jewelry to emphasize both their social belonging and their superiority over the Phanariots and, especially, their princely entourage of "Greeks". 7

The boyars took inspiration from both Ottoman and European clothing trends, which they saw at the Phanariot court and during their travels, as well as in books and magazines. At the Phanariot court the influence of Turkish fashion was strong and affected even foreigners, but there was also a presence of Europeans and European dress. Doctors, cooks, and men of letters came

5 The term became current in the eighteenth century, with the installation of the Phanariot regime, as a replacement for the Slav term blagorodnic. Evghenit derives from the Greek evgenia and means "noble, boyar" as does blagorodnic. Some boyars underlined their belonging to the protipendadă (great boyar class) by describing themselves as "boyar evghenit and blagorodnic". The term protipendadă came into use in the same period, through the intermediary of the Greek spoken both in the princely chancery and at court, from the Greek próti pendáda.

6 Constanţa Vintilă-Ghiţulescu: Evgheniţi, ciocoi, mojici. Despre obrazele primei modernităţi româneşti (1750-1860) [Boyars, Upstarts, Peasants. Romanian Faces of the Modernization]. Bucharest 2013.

7 "Greeks" is the generic name used in the period to denote all Orthodox Christians coming from the other side of the Danube, from the Ottoman Empire, who monopolized commercial activity and the skilled trades. Some of them came in the suite of the Phanariot rulers and received important offices in the princely divan, while others came in search of a better life, pursuing various occupations: teachers, artisans, merchants, mercenaries, etc. 
from across Europe to be at the service of the Phanariot rulers. Some of them kept their European clothes while others adopted the local variety of Turkish fashion. One of the latter was the French painter Jean-Etienne Liotard, who in 1742-1743 was called to the court of Prince Constantine Mavrocordat in Iaşi to make portraits of the princely family. ${ }^{8}$

The boyars requested "gazettes" and fashion magazines from Europe, not only to be informed about political changes, but also to stay up-to-date with the latest developments in matters of fashion. ${ }^{9}$ For instance, on 7 April 1777, Grand Vistier (treasurer) Ioan Canta bought four volumes of the Encylopédie, the famous French dictionary of Enlightenment edited by Denis Diderot. ${ }^{10}$ The boyar Iordache Slătineanu read the British magazine of politics and culture The Spectator and the French women's literary almanac Almanach des Dames. ${ }^{11}$ In Iaşi, in 1806, Charles Frédéric Reinhard, Consul General of France in the two principalities, encountered boyars reading the French fashion magazine $L e$ Journal des modes. ${ }^{12}$

The boyars' interest in various European periodicals suggests that they also purchased Ottoman costume books. These albums, with illustrations of the different peoples living in the sultan's realm, were a principal source of inspiration for the European nobility. ${ }^{13}$ They were "produced by European artists for

8 On Liotard's presence in Iaşi: Remus Niculescu: Jean-Etienne Liotard à Jassy, 1742-1743, in: Genava 30 (1982), 127-166. See also his portrait of the Moldavian princess Ekaterina Mavrocordat, 1742-1743, Kupferstichkabinett, Staatliche Museen zu Berlin, inv. KDZ 1626.

9 In the correspondence of the boyar Barbu Ştirbei with the Constantin Hagi Pop commercial house in Sibiu, the insistence with which German, Greek, and Italian "gazettes" are requested may be observed. See the letters of 22 March 1784, 26 July 1784, 24 February 1793, 20 November and 25 December 1795, 28 January 1798, 18 November 1799, Nicolae Iorga: Scrisori de boieri şi negustori olteni şi munteni către casa de negoț sibiiană Hagi Pop. Bucharest 1906, 8-9, 27, 32, 35, 37. The journals published in Leipzig at the time were: Damenjournal von einer DamenGesellschaft (1784); Journal, Fabrik, Manufakturen und Handlung, Kunst und Mode (1792); Charis. Ein Magazin für das Neueste in Kunst, Geschmack und Mode, Lebensgenuß und Lebensglück (1801); Zeitung für die Elegante Welt (1801).

10 Serviciul Judeţean al Arhivelor Naţionale, Iaşi [Departmental Archives, Iaşi] (hereafter SJAN), Colecţia Documente P. 1023/2, "Sama lui Şerban logofăt pentru cheltuiala casii dumisale Ioan Canta biv vel vistier pe anul acesta, precum arată anume înăuntru, leat 1777 ghenuar 1”.

11 Alexandru Alexianu: Mode şi veşminte din trecut, vol. 2. Bucharest 1987, 147.

12 Paul Cernovodeanu et al (eds.): Călători străini despre țările române în secolul al XIX-lea: serie nouă, vol. 1. Bucharest 2004, 273-274.

13 Giulia Calvi: Across Three Empires. Balkan Costumes in 16th-Century Europe, in: Constanţa Vintilă-Ghiţulescu (ed.): Traditional Attire to Modern Dress. Modes of Identification, Modes of Recognition in the Balkans (XVIIth-XXth Centuries). Newcastle 2011, 29-52; Robert Born: Mapping Transylvania as a Multiethnic and Multiconfessional Region in Costume Books (17th-19th Centuries), in: ibid., 53-83. 
a European public" and also used by foreign diplomats in the course of their missions in order to identify Ottoman officials. In the eighteenth century, the Ottoman elite also became interested in the production and acquisition of such albums. ${ }^{14}$ However, sources on the principalities are scarce and, to date, I have not discovered a "costume book" in the Wallachian and Moldavian archives.

\section{Vestimentary Signs and Social Distinction}

There were a number of easily recognizable elements that made up what contemporaries in the principalities perceived as Turkish dress. The following discussion focuses on several of these clothing items and accessories, which the boyars adopted in a very specific way that left room for their individual strategies of social distinction. I begin with different forms of men's headgear, then examine shawls and other luxurious clothes and accessories for women, and finally turn to consider valuable furs worn by both elite men and women in the principalities.

\section{The Boyar's Headgear}

The işlic, a high hat that derived its name from the Turkish başlıkŭ, was a typical feature of a boyar's dress and offered visual evidence of his rank, social position, and status [Figure 1]. ${ }^{15}$ This headwear was permitted to all Christians in the Ottoman Empire; yet in the Romanian lands especially it took on a symbolic dimension. There was a great variety of işlic available in the principalities. The Moldavian Grand Vistier Ioan Canta in his chronicle Record of Expenses mentions the following varieties: "işlic of sable for the groom"; light grey işlics (of lambskin); "Moldavian işlics"; "Nogai işlics"16; night kavuks; and kalpaks, made and adorned by Ştefan the işlic-maker or Păun, the head of the kalpak-makers' guild (kalpakci-başa). ${ }^{17}$ The guild of işlic-makers in Bucharest

14 Suraiya Faroqhi: Introduction, or why and how one might want to study Ottoman clothes, in: Suraiya Faroqhi and Christoph K. Neumann (eds.): Ottoman Costumes. From Textile to Identity. Istanbul 2005, 20.

15 On clothes with regard to rank and social status in the Ottoman Empire see Donald Quataert: Clothing Laws, State, and Society in the Ottoman Empire, 1720-1829, in: International Journal of Middle East Studies 29 (1997), 406.

16 From the name of the Tatar tribe.

17 SJAN, Iaşi, Colecţia Documente P. 1023/2, accounts for 17 January 1777 and 12 April 1777. 


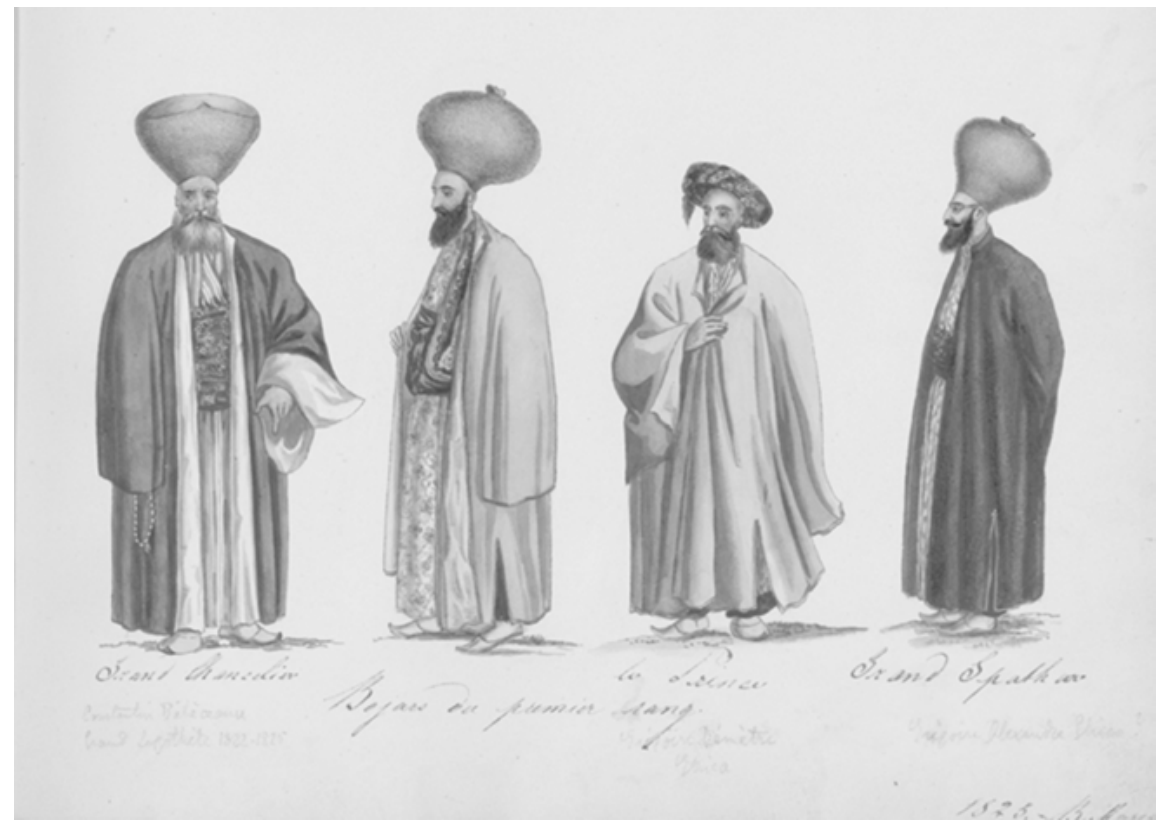

Figure 1: Auguste de Henikstein: High-Ranking Boyars, 1825, drawing, $199 \times 250 \mathrm{~mm}$. Courtesy $(C$ Library of the Romanian Academy.

was very powerful and often appealed to the prince for the punishment of leather-workers or furriers who did not respect the guild members' exclusive right to make işlics. ${ }^{18}$ The guild's repeated appeals also attest to the considerable income to be obtained by practicing this trade, as the demand for işlics was nearly universal.

The features of this particular headgear were strictly regulated. Depending on its size, form, material, and color, the işlic told the story of its wearer. The Phanariot prince and his sons, the beyzades, as well as the five foremost officeholders of the ruler's divan, wore isslics covered with sable fur. But while the prince was entitled to a gugiuman (Turkish gücemin) of sable fur with a white top, the great boyars were entitled only to sable gugiumans with red tops. And while the great boyars in high offices wore large round işlics, the petty boyars wore small round işlics topped by a felt square colored according to their rank and office. ${ }^{19}$

18 Vasile Alexandrescu Urechia: Istoria românilor, vol. 1. Bucharest 1891, 439-443.

19 Furnică, Industria, 213. For a discussion of the social and political signification of headgear in the Ottoman Empire see Patricia L. Baker: The Fez in Turkey. A Symbol of Modernization?, in: Costume 20 (1986), 72-85. 
The işlic and kalpak of boyars lower down the social hierarchy were covered with fur of lower quality, namely marten, lamb, fox, or polecat.

The type of isslic a man wore also indicated his proximity to the center of power. Investiture to high office took place in a public ceremony, in which the newly appointed boyar was given a new işlic and caftan, and, agreeing to respect his elevated position, thus "put on" the identity of the social group he had entered. With high office, that is, came a new costume, one that maintained the official's position in the social hierarchy, underlined his prestige and grandeur, brought recognition in public, and induced submission and fear. Indeed, when a great boyar appeared in public, displaying his işlic, his caftan with furs, and his beard, it called for an immediate recognition of his power. In the 1820s, the boyar, author, and member of the prince's council, Grand Logofăt (chancellor) Dinicu Golescu, described the effects of this visibility of his social status as follows: "Seeing me with my beard they recognized that I was of divan rank." He then goes on to tell of the complete submission he induced when he appeared on the roads of Wallachia in the garb of an ispravnic (county prefect): the common people threw themselves on the ground, he says, with "their heads bare, as if condemned to death". ${ }^{20}$

Of course, the significance of the isslic was renegotiated as the men wearing them transgressed social boundaries, misused their privileges, and carried the form of the headgear to excess. According to legend, boyars owned two sets of hats: one that was permitted by their rank and office, and another one for their own pride, which was worn especially among friends and which tended to be much larger and more richly ornamented. ${ }^{21}$ Possibly, this "fashion for işlic grandeur" was inspired by the example of the viziers of Sultan Mustafa III (r. 1757-1773), who "pressed for turbans grander than those worn by more illustrious forerunners". ${ }^{22}$ The fashion for immense işlics, however, gave rise to pamphlets and caricatures in which the hats and their wearers were mocked. In the Gromovnic, a book of astrological predictions from 1795 , the anonymous author sketched several boyars' heads, adding an ironic note to each sketch: "boyar with a gugea on his head"; "boyar with a lamp on his head"; and "boyar with breadcrumbs on his head" [Figure 2]. ${ }^{23}$ From there, it

20 Dinicu Golescu: Însemnare a călătoriii mele, Costandin Radovici din Goleşti făcută în anul 1824, 1825, 1826. Bucharest 1977, 137.

21 Radu Rosetti: Amintiri. Ce am auzit de la alţii. Bucharest 1996.

22 Madeline Zilfi: Whose Laws? Gendering the Ottoman Sumptuary Regime, in: Faroqhi and Neumann, Ottoman Costumes, 135.

23 Library of the Romanian Academy, Fond Carte Rară, CRV 587, Gromovnic al lui Iraclie împărat carele au fost numărătoriu de stele, acum a doua oară tipărită la leat 1795. [hereafter BAR] 


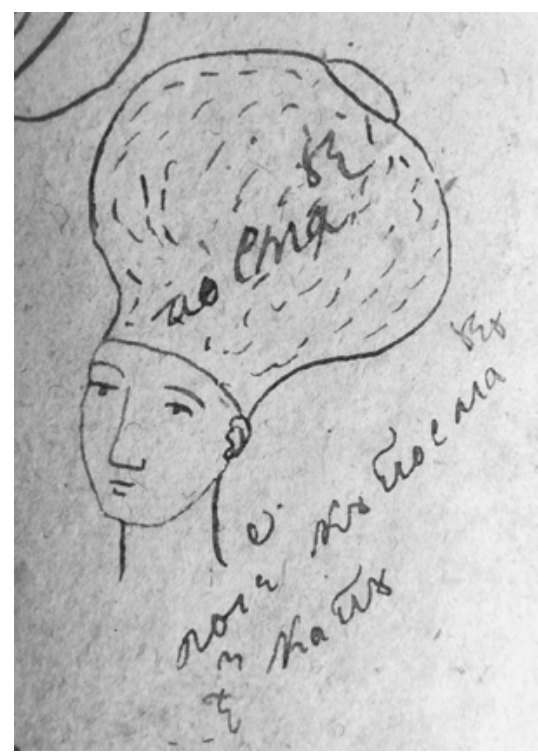

Figure 2: Detail of a boyar headwear, in: Gromovnic al lui Iraclie împărat carele au fost numărătoriu de stele, acum a doua oară tipărită la leat 1795. Courtesy @ Library of the Romanian Academy.

is but a short step to the negative image of the isslic "as tall as the obelisk in the public gardens", which certain modern scholars have seen as proof of the vanity of the boyars, who were proud of their ornaments but unashamed that they could not read or write. ${ }^{24}$

To foreigners who passed through Moldavia and Wallachia on the way to Istanbul at this time, the boyar's işlic was a source of amusement in its extravagant shape and size. Considered "odd", and as such noteworthy, the işlic became the subject of a series of narrative and visual depictions. The Scottish diplomat, traveler, and painter Robert Ker Porter, for instance, left an account of boyar işlics, accompanied by several sketches. In 1818, during his stay at the Wallachian court in Bucharest, he was invited by Prince Scarlat Callimachi to attend a concert, which gave him the opportunity to observe and to draw the locals and their headgear. He writes:

I amused myself in silently sketching some of their figures. The general costume was Turkish, and of every-coloured brocade, embroidered, and befurred; so far all was well, till the huge Whalachian cap turned the whole ridiculous. It is of a pumpkin form, nearly three feet in circumference, and of an equally enormous height. The material, a grey silvery Bucharian lamb-skin, with a tassel at the top, to assist the wearer in taking it off

24 Alecu Russo: Cântarea României. Bucharest 1980 [first edition 1850], 82-83. 
when he means to salute an acquaintance. This little appendage is green with every person, excepting the royal family, and they have it white. The cap of the lower orders is of the same shape, but not quite so large; and a square cushion covered with dark cloth is its enormous crest; in fact all these people appear so top-heavy it is painful to look at them, after the first risible impression of the absurd passes away. ${ }^{25}$

The boyars did not wear only the işlic; they also wore turbans and other garments from the Ottoman Empire. Yet while there are various sources on dress in Istanbul and other places of the empire, including regulations concerning the color of turbans, ${ }^{26}$ evidence with regard to the Romanian lands is scarce: a series of portraits, a couple of written sources, and the terminology used for specific items. Nevertheless, these sources indicate that, like other Christians in the Ottoman Empire, the Romanian boyars also wore striped taklids and çalmas. Taklid, or taclit, was a shawl worn around the waist, holding the typical anteri coat tightly. Çalma, or cialma, were shawls worn around the head as turbans. For instance, in the 1820s, the Serbian painter Pavel Djurcovic made portraits of the young boyars Constantine Cantacuzino and Iancu Manu wearing the çalma turban. [Figure 3, Figure 4]. While taklids and çalmas were worn by the great boyars with important offices in the divan, lesser boyars and servants of the princely court wore donluks around their heads, a turban of cloth of inferior quality. ${ }^{27}$ The Customs Catalogue from 1 January 1792 specifies that "taklids of alagea (linen silk)" came from Aleppo, while donluks were brought from Istanbul. ${ }^{28}$ At a safe distance from the imperial center, the Romanian lands escaped the more rigorous dress codes of the empire, where - as Matthew Elliot has shown - Christians at some point lost the right to wear turbans and were prescribed to wear only the işlic and the kalpak. ${ }^{29}$ In the principalities, by contrast, a boyar could put a çalma or taklid on his head without fearing for his life. However, if he were to have traveled in the Ottoman Empire, he would have had to catch up on the latest dress regulations in advance, because wearing the wrong clothes could have cost him his head. This is what happened, for instance, to the young boyar Aleco Vlahuţi at the beginning of the nineteenth century. When he arrived in Istanbul he had a sark (silk cloth) wound around

25 Sir Robert Ker Porter: Travels in Georgia, Persia, Armenia, Ancient Babylonia \& c. During the Years 1817, 1818, 1819, vol. 2. London 1822, 787-788.

26 Matthew Elliot: Dress Codes in the Ottoman Empire. The Case of the Franks, in: Faroqhi and Neumann, Ottoman Costumes, 105-106.

27 Arhivele Naţionale Istorice Centrale [National Historical Central Archives], Bucharest (hereafter ANIC), Fond Manuscripts, Ms. 1773, fol. 19-20.

28 Urechia, Istoria românilor, 246.

29 Elliot, Dress Codes, 106. 


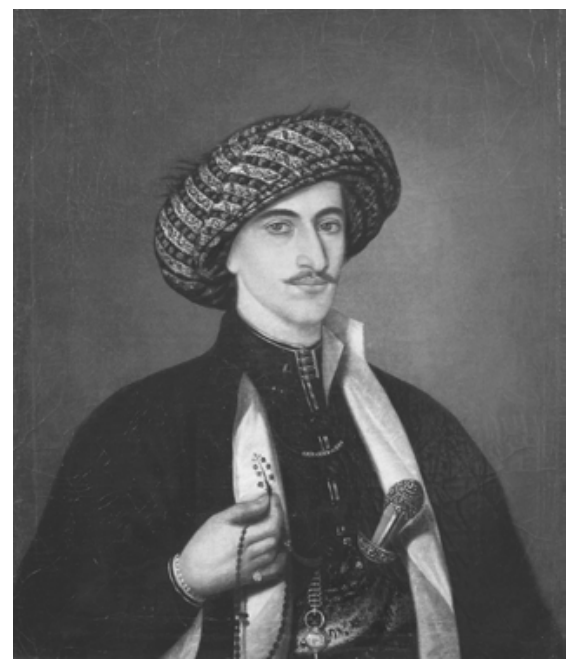

Figure 3: Anonymous: Portrait of lancu Manu, oil on canvas, 0,755 x 0,630 m. Courtesy (C) National Museum of Art, Bucharest.

his head, not knowing that this particular form of headgear had just been forbidden. It was enough to be spotted at the window of a house in the village of Therapia on the Bosporus by the bostancıbaşı, the head of the palace guards, who happened to be passing, for him to be condemned to death. ${ }^{30}$

\section{Shawls and Textiles for the Boyar Ladies}

Female members of the Romanian elite also were influenced by fashion trends from the Ottoman Empire and similarly used certain clothing items, such as shawls, as a means of social distinction. Giulia Calvi has emphasized how cashmere shawls connected "material modernity, distinction, and taste" to construct hierarchy and status. ${ }^{31}$ Having arrived in Istanbul from India, cashmere shawls quickly spread throughout Europe. They were considered a highlight in

30 Nicolas Soutzou: Mémoires du Prince Nicolas Soutzo, grand-logothète de Moldavie, 1798-1871.Vienna 1899, 55-59.

31 Giulia Calvi: Translating Imperial Practices, Knowledge, and Taste Across the Mediterranean. Giulio Ferrario and Ignatius Mouradgea d'Ohsson, in: Constanţa Vintilă-Ghiţulescu (ed.): Women, Consumption, and the Circulation of Ideas in South-Eastern Europe, 17th-19th Centuries. Leiden 2017, 20. See also Giulia Calvi's contribution to this volume. 


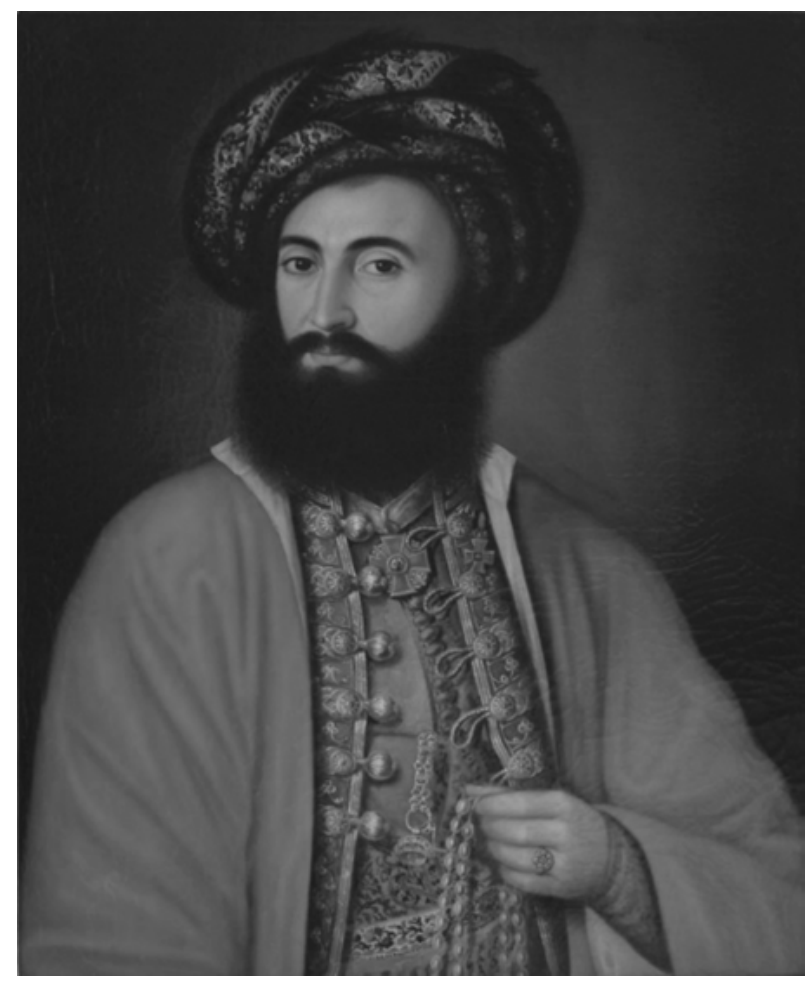

Figure 4: Pavel Djurcoviciu: Constantin Cantacuzino, 1820, Wikimedia Commons https://en.wikipedia.org/wiki/File:Pavel_Đurković_(attrib.)_-_Constantin_Cantacuzino.png.

a woman's appearance and were soon adored by Italian noblewomen ${ }^{32}$ and found in the wardrobes of ladies of French high society. ${ }^{33}$ This can be seen in paintings of the time, such as the portrait of "Frau Luise Mila" by the German painter Johann Erdmann Hummel, which shows an elite woman with a red cashmere shawl draped over her shoulders in the 1810 s. $^{34}$

32 Giulia Calvi: Luxury comes from the East. Fashioning "à l'indienne" between the Ottoman Empire and Italy (XVIII-XIX), unpublished paper read at the international workshop People, Trade, Gifts and Beyond. The Circulation of Goods and Practices between the Ottoman Empire and Europe (16th-19th Centuries), Berlin, 4-5 July, 2016.

33 For the fashion for shawls, which became a ubiquitous accessory, see the recommendations in the illustrated magazines of the day: Journal des Dames et des Modes and Costumes parisiens, 1798-1812. URL: http://gallica.bnf.fr/ark:/12148/bpt6k57090g/f18.image (30 Nov. 2017).

34 Alte Nationalgalerie, Berlin, Johann Erdmann Hummel, Frau Luise Mila, 1810. 
The shawl also served as an important accessory in the visual representation of upper-class women from the Danubian Principalities. Almost all the portraits of female members of the Romanian elite produced between 1780 and 1840 show a seated woman and her shawl. These shawls are presented in the finest detail, and are not simply left on couches awaiting their mistress but cover her shoulders, are haphazardly thrown over her body - which is also adorned by other luxury items and insignia of power - or decorate an item of furniture in the background of the picture. ${ }^{35}$ [Figure 5]

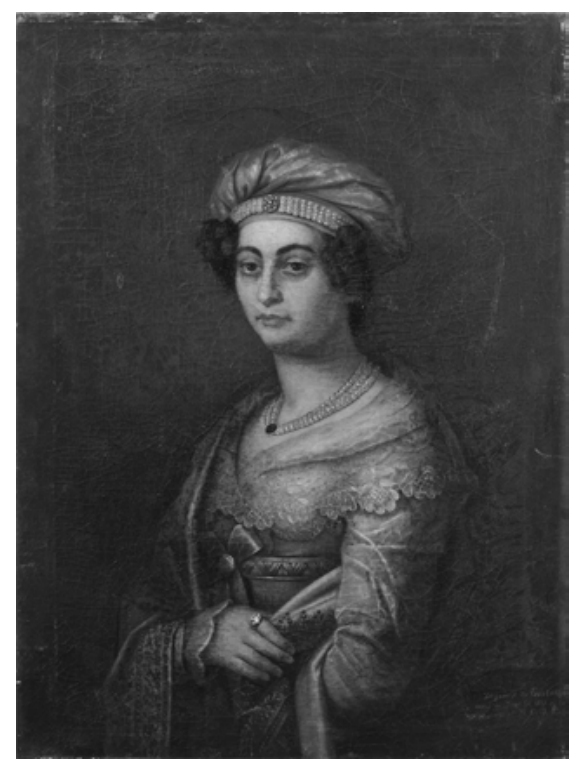

Figure 5: Eustaţie Altini: Portrait of a woman, 1813-1815, oil on canvas, $0,865 \times 0,640 \mathrm{~cm}$. Courtesy $(\odot)$ National Museum of Art, Bucharest.

To cover their shoulders, the wealthy ladies of the boyar elite cherished cashmere shawls and shawls made of giar, a valuable fabric made from camel hair and decorated with flowers and embroidery in gold or silver thread. Moreover, both cashmere and giar were the preferred material for other valuable garments as well. The soft and velvety cashmere was often used for Turkish-style trousers, which were worn by women and men alike and which appear in the sources as

35 See the portraits in the Gallery: Romanian Modern Art, Romanian National Museum of Art, Bucharest. 
"çaksir of shawl" or "cintieni of shawl". ${ }^{36}$ For instance, the dowry of a boyar lady from 1775 lists a "cübbe (overcoat) of shawl cloth with laces of gold thread, without fur". ${ }^{37}$ Giar was used for overcoats as well. The dowry of a boyar lady from 1797 lists among her belongings "a cübbe of giar, fur-lined with polecat". 38 On their heads boyar ladies wore sanks, a sort of silk cloth adorned with numerous precious stones or embroidered flowers. There are descriptions of this particular type of head-covering by Andreas Wolf, a Transylvanian Saxon doctor at the princely court of Moldavia between 1780 and $1783,{ }^{39}$ and by the naturalist Balthazar de la Motte Hacquet, who provides an engraving of a sark and writes: "a boyar's wife usually wears a sank of thin silk or muslin, in the form of a sugar loaf, adorned with pearls and other jewels and with all sorts of ribbons and flowers. Her hair is twisted over it in one or more plaits, or plaited into a long pigtail. At the peak of this head ornament is a tassel, and on one side or in front it is adorned with two ostrich feathers." 40

The Customs Catalogue published on 1 January 1792 indicates the provenance and price of several of these clothes and accessories, underlining their value as luxury items vis-à-vis similar products. Ordinary shawls imported from Egypt and sold in the shops of Romanian towns, for instance, were not of great interest to the wealthy boyars. ${ }^{41}$ Instead, they chose the expensive shawls, some of them "adorned with jewels and pearls", which were brought from India, Damascus, Aleppo, or Chios, first to Istanbul and from there to the principalities. $^{42}$ The correspondence of a commander of the princely guard, Delibaşa Gheorghe Constantin, who was involved in the luxury trade selling

36 BAR, Fond Episcopia Buzău, LXXXV/53, 26 January 1791.

37 BAR, Fond Documente Istorice, CCXLVII/182, 13 September 1775.

38 BAR, Fond Documente Istorice, MLXXXVI/34, 19 September 1797.

39 Andreas Wolf came to Moldavia in 1780 and stayed at the court until 1783. In 1784 he was in Wallachia, returning to Moldavia in 1788-1790 and 1796-1797. He wrote Beiträge zur einer statistisch-historischen Beschreibung des Fürstenthums Moldau. Hermannstadt 1805. See Cernovodeanu, Călători străini, vol. 10:2, 1277.

40 Balthasar la Motte Hacquet: Hacquet's neueste physikalisch-politische Reisen in den Jahren 1788 und 1789 durch die Dacischen und Sarmatischen oder Nördlichen Karpathen, vol. 1. Nürnberg 1790, 138f., see Cernovodeanu, Călători străini, vol. 10:2, 830. See also the engraving 'Boyarin aus der Moldau', Balthazar de la Motte Hacquet, 1790, in the French edition of his book L'Illyrie et le Dalmatie, ou mours, usages et costumes de leurs habitants et des ceux des contrées voisines. Paris 1815.

41 See the list of prices in Catalogul vămilor (The customs catalogue) for the taxing of goods entering Bucharest in 1792. Urechia, Istoria românilor, vol. 4, 1891, 246.

42 La Motte Hacquet, Hacquet's neueste physikalisch-politische Reisen, vol. 2. Nürnberg 1791; See Cernovodeanu, Călători străini, vol. 10:2, 844. 
shawls and gold jewelry with diamonds, hints at the market value of cashmere and giar products from India. It suggests that a giar was worth 500 silver coins (groschen), which was a considerable sum of money. On 17 December 1813, Constantin noted that, from among the goods he had received from Lahore via Constantinople, he had sold fifteen shawls and five giars in Bucharest and sent another six shawls and one giar to Moscow, because they could not be sold locally. The deal brought him and his associates, Greek merchants in Constantinople, no less than 10,803 groschen. ${ }^{43}$ Indeed, although a sumptuary law from 1778 (discussed in more detail below) stated that cashmere and giar shawls were "useful against the cold and durable", ${ }^{44}$ and the fabrics were therefore not forbidden, the use and visual depiction of luxury items made of these materials shows that there was obviously more to it than the practical aspects alone.

\section{The Boyars' and Boyaresses' Furs}

Following the Ottoman model, the Romanian boyars and their wives wore rich and varied furs, regardless of the season. ${ }^{45}$ Constantine Caracaş, a Greek doctor in Bucharest at the beginning of the nineteenth century, notes that the boyars wore many furs "one on top of the other", both in winter and in summer, and moreover adorned many other items of clothing with furs, while "the elegant bodies of the ladies were wrapped in light furs and heavy dresses of material from India, silk or goldwork." ${ }^{46}$ Certain furs were very expensive and therefore traditionally formed part of ceremonials. They featured in the investiture of rulers, including the enrobing of boyars, and in the reception of diplomatic missions, as well as in the ritual exchange of gifts. Particular furs were also associated with a distinct position within the political hierarchy and with specific occasions. For instance, silk overcoats (cübbe) with ermine fur were worn only by the Grand Vistier and only on official occasions at the princely court. His everyday garments were adorned with squirrel or fox fur. ${ }^{47}$

It is no wonder that the boyars and their wives saw in furs an important means of social distinction and spent huge sums of money in order to buy

43 ANIC, Fond Achiziţii Noi, LXXVII/7, 9, 10, 11, 12-17 December 1813.

44 BAR, Fond Carte Rară, CRV 443A, fol. 12r.

45 Hülya Tezcan: Furs and Skins owned by the Sultans, in: Faroqhi and Neumann, Ottoman Costumes, 63-79.

46 Constantin Caracaş: O veche monografie a Munteniei de dr. Constantin Caracaş (1800-1828). Bucharest 1937, 107.

47 SJAN, Iaşi, Colecţia Documente P. 1023/2. 
expensive furs and fur adornments for their overcoats, headwear, and robes. There was a great variety of furs of different quality and price they could choose from. The Customs Catalogue of 1 January 1792 lists the furs available in the principalities according to their market value: furs of "black fox" were the most valuable, followed by "the good sables of Russia", so-called to distinguish them from "the poorer sables that come from Russian Lehia [Poland]" and "the sables of Beciu [Vienna]". For the less wealthy, the market also offered furs from ermine; black and Siberian polecats; red, white, and "Cossack" foxes; martens; and lynx, down to the everyday furs of rabbits and foxes. ${ }^{48}$ The most expensive furs arrived every spring from Russia, ${ }^{49}$ and those were the ones on which the elite spent most of their money. Alexandre d'Hauterive, the French secretary of Prince Alexander Mavrocordato Firaris (r. 1785-1786), saw how "Moldavians ruined themselves by buying expensive textiles and pelisses."50 For example, the former Grand Vistier Ioan Canta spent considerable sums on cubits of silk fabric called ghermeşut silk (from Turkish germsud) imported from Damascus and Istanbul and on a silk fabric embroidered with silver or gold thread called sevai (from Turkish sevayi) ${ }^{51}$; these materials were then turned into "a cübbe lined with sable", "a red cübbe of altân [felt cloth with gold thread] lined with sable", and coats well adorned with the sable of "Mosc[ow]", Russian polecat (sângeapi), and the furs of squirrels, foxes, and mink. ${ }^{52}$

\section{Dress and Politics: The Phanariot Reaction to Boyar Luxury}

The opulent luxury of the boyars was not only a recurrent theme in the eyewitness accounts of the period. ${ }^{53}$ It was also a phenomenon to which the

48 Urechia, Istoria Românilor, vol. 4, 248-249.

49 Ignatius Stefan Raicevich: Observazioni Storiche, naturali e politiche intorno la Valachia et la Moldavia. Naples 1788, 134. The author was the Ragusan secretary of Prince Alexander Ypsilantis.

50 "Les moldaves se ruinent en étoffes et en pelisses," Alexandre Maurice Blanc de Lanautte comte d'Hauterive: Mémoire sur l'état ancien et actuel de la Moldavie (1787). Bucharest 1902, 322. 51 From the Turkish sevayi, silk fabric embroidered with silver or gold thread.

52 SJAN, Iaşi, Colecţia Documente P. 1023/2, f. 52. The purchases are listed for 10 December 1776, 7 April 1777, and 5 April 1777.

53 See for instance the account written by Charles-Marie d'Irrumberry conte de Salaberry, who travelled to Istanbul in 1796 and made a long stop in Bucharest. He is amazed by the "opulent luxe" of the Wallachian boyars dressed up in "Indian fabrics, shawls and sable 
Phanariot rulers had to pay attention, and they did so in a number of ways. Some Phanariot rulers supported the boyars' appetite for luxury. The chronicler Ion Neculce (1672-1745), a very wealthy boyar of early eighteenth-century Moldavia, writes that the Phanariot prince Gregorios Ghika (r. 1726-1733) "desired" that the court of Iaşi "be well dressed". ${ }^{4}$ He asked the boyars, regardless of their material condition, to put on rich garments when they made an appearance at court. ${ }^{55}$ At the opposite extreme was Prince Constantine Mavrocordato, who ruled several times over both Wallachia and Moldavia between 1726 and 1752. ${ }^{56}$ A "rational" erudite, the ruler promoted moderation in all things. His own public appearances were lessons in modesty and simplicity. He also adopted an austere lifestyle: "He would get up early in the morning at five o'clock of the night and would stand in the church with great attention and piety, together with all the boyars and princely servants who dwelled at the princely court.” The prince despised luxury and "the pleasures and pastimes of life", exiling music from the princely court and adopting fasting, prayer, and humility, thus presenting an example that could not be ignored. Indeed, according to the chronicler of the time, the boyars felt they had to remodel their public appearances according to the princely model: "Many of the great boyars were obliged to imitate the harsh fasts that he kept", give up tobacco, and "keep a rein on their bodily desires". 57

However, the Phanariot rulers were often reluctant to curb the luxury and opulence of the local elites, because of their short reigns (only three years at a time) and the difficulty of implementing regulations regarding boyar lifestyle. For instance, Prince Gregorios Alexander Ghika (r. 1777-1782) of Moldavia reportedly "considered giving the command not to wear all sorts of garments", but did not have the courage to issue such a law, because "it might be that many [boyars] would not take this command into account." He knew that he would have to impose any such measure by force and did not dare punish the powerful boyars loved by the people. Instead, in order to not "look bad before the common people", he followed the above-mentioned model of Prince

furs”. M. le Comte de Salaberry: Essais sur la Valachie et la Moldavie, theatre de l'insurection dite Ypsilanti. Paris 1821, 35.

54 He ruled several times: in Moldavia 1726-1733, 1735-1739, 1739-1741, 1747-1748; in Wallachia 1733-1735, 1748-1752.

55 Ion Neculce: Letopiseţul Ţării Moldovei. Chişinău 1990, 436.

56 He ruled several times: in Wallachia, 1730, 1735-1741, 1744-1748, 1756-1758, 1761-1763; in Moldavia, 1733-1735, 1741-1743, 1748-1749.

57 Nestor Camariano and Ariadna Camariano-Cioran (eds.): Cronica Ghiculeştilor. Istoria Moldovei intre anii 1695-1754. Bucharest 1965, 621-623. 
Constantine Mavrocordato. The chronicler of the time writes: "His Highness made for himself alone a suit of clothes of felt, libade and cübbe, and one day, without announcement, he came out dressed in them to the divan." Faced with the modest and frugal image presented by the ruler, the boyars could not but conform, at least when they were guests at the princely court: "Seeing this, the native boyars began also to make themselves libades and cübbes of felt." 58 Still, the felt coats were probably cast aside as soon as Prince Gregorios Alexander Ghika lost his throne and another prince, much more indulgent in matters of clothing, was installed.

This example underlines how fragile were the power relations between the native elite and the Phanariots. As has been mentioned, the boyars' social status had previously been based on birth rights: their belonging to an ancient family had given them the right to rise to the top of the social hierarchy, a social ascent that showed in their clothing, carriages, country houses, and heraldic insignia. ${ }^{59}$ But with the arrival of the Phanariot rulers and their entourage, the Romanian boyars became excluded from direct access to high office. They entered a fierce competition for the most prestigious positions, investing in a "culture of appearances" 60 that proved ruinous to all sides. Moreover, a new social group emerged and made its appearance on this stage: the merchants who had enriched themselves from trade in luxury products. Profiting from this fluid redefinition of social groups, some of them bought ranks and offices, executed skillful matrimonial strategies, and entered the privileged group of the great boyars.

It is in this context that sumptuary laws appeared in the principalities. They testify to the Phanariot rulers' efforts to control state and society and regulate social mobility within the elite, whose composition changed with every change on the throne. Sartorial regulations existed in many places and were a common means by which authorities tried to control the wealth of the elite and regulate social distinction. ${ }^{61}$ These sources therefore tell us about the competition between rulers, members of the elite, and those who tried to enter

58 Pseudo-Enache Kogălniceanu and Ioan Canta: Letopiseţul Ţării Moldovei de la domnia întâi şi până la a patra domnie a lui Costandin Mavrocordat vv. (1733-1774), ed. by Aurora Ilieş and Ioana Zmeu. Bucharest 1987, 117-118.

59 Claire Sponsler: Narrating the Social Order. Medieval Clothing Laws, in: Clio 21 (1992), 265-283, here 266.

60 An allusion to Daniel Roche: La culture des apparences. Une histoire du vêtement XVII ${ }_{-}$ XVIII ${ }^{e}$ siècle. Paris 1989.

61 On Europe, see Alan Hunt: Governance of the Consuming Passions. A History of Sumptuary Law. New York 1996; Graeme Murdock: Dressed to repress? Protestant Clerical Dress and the Regulation of Morality in Early Modern Europe, in: Fashion Theory 4 (2000), 179-199; Catherine Kovesi Killerby: Sumptuary Law in Italy 1200-1500. Oxford 2002; Kate 
these privileged circles. But they do not only "narrate the social order" ${ }^{2}$; they also highlight the need to affirm power relations through consumption and social practices. Because although luxury was often stigmatized as "the source of the devil", as for instance by Rousseau in his Discourses, ${ }^{63}$ it nevertheless proved indispensable in the display of social identity. In most parts of Western Europe, sartorial regulations became sporadic in the eighteenth century. ${ }^{64}$ In the Ottoman Empire, such regulations appeared in the context of an increased social mobility, a "social opening", 65 and continued to exist until late in the nineteenth century. ${ }^{66}$ In the Romanian lands, clothing laws were promulgated only during a short period, belated in relation to Western Europe but not to the Ottoman Empire: the first sumptuary law dates from 1778, the last from $1815 .^{67}$

The Romanian clothing laws were inspired by the Ottoman model. The Phanariot princes, as high officials in the Ottoman administrative system, were familiar with such texts, and the boyars travelled often enough to the empire's main cities to know about Ottoman sartorial regulations. The Wallachian high official and diplomatic agent Ianache Văcărescu (1740-1797) writes in his History of the Most Powerful Ottoman Empire about the reforms of the sultan of his time, Sultan Mustafa III (r. 1757-1773): "He changed the debauched clothes both of the subjects (re'ayas), with the command that all should wear black clothes in Istanbul and elsewhere, excepting only Vlaho-Moldavia, and of the Turks, both with a command to wear simple clothes and by example, for the Emperor himself wore them." The author underlines that while these dress regulations did not apply in the territory of the tributary principalities, they still served the Phanariot ruler Constantine Mourouzis (r. 1777-1782) as an example and made him appear in public in "plain clothes". 68

Dimitrova and Margaret Goehring (eds.): Dressing the Part. Textiles as Propaganda in the Middle Ages. Turnhout 2014.

62 Sponsler, Narrating.

63 Jeremy Jennings: The Debate about Luxury in Eighteenth and Nineteenth-Century French Political Thought, in: Journal of the History of Ideas 68 (2007), 81.

64 Ulinka Rublack: Dressing Up. Cultural Identity in Renaissance Europe. Oxford 2010, 265-270.

65 Quataert, Clothing Laws, 406.

66 Ibid., 403-425.

67 In Romanian historiography, sumptuary laws have been more often cited than analysed. See: Alexianu, Mode şi veşminte; Adrian-Silvan Ionescu: Modă şi societate urbană în România epocii modern. Bucharest 2007; Ioan-August Guriţă: Gavril Callimachi. Mitropolitul Moldovei (1760-1786). Iaşi 2017, 322-325.

68 Ianache Văcărescu: Istoria Othomanicească, critical edition, introductory study, notes, and glossary by Gabriel Ştrempel. Bucharest 2001, 94. The author held the positions of grand 
The first sumptuary law in the principalities was issued in 1778 by Prince Constantine Mourouzis, but it was crafted by the head of the Orthodox Church in Moldavia, Metropolitan Gavril Kalimaki. It also includes the signature of Patriarch Avram of Jerusalem, as well as a curse on all men and women who would not submit to the command of these political and religious authorities. The law did not prohibit a particular fashion or color but rather certain rich fabrics and ornaments that added value to men's and women's garments: "taffeta, cumaş (from Turkish Kumaş, silk fabric), ghermeşut from India, Şam [Damascus], T3arigrad [Istanbul], or Europe woven with wire (fir), braid (peteală), gold and silver thread (sârmă), or flowers of silk.” The latter ornaments were all forbidden. Clothes had to be "plain", made of fabrics without other threads added and without adornments, braid, or lace. However, as mentioned above, cashmere shawls and giars did not come under the interdiction, with the explanation that they protected from the cold. Also excluded were the valuable caftans used by rulers to invest new officials, those offered to brides, and other textiles used at weddings. ${ }^{69}$

The text of the law mentions economic and moral concerns as the motives behind the legislation. This line of argumentation reappears in later sumptuary laws, including, for instance, one promulgated in 1794, which prohibited the import of expensive fabrics, and one promulgated in 1796, which forbade the import of carriages in order to support local manufacturers. ${ }^{70}$ The 1778 law condemned "the grand houses of the great boyars" who went into debt "out of pride", wasting their fortunes on the "vanity" of appearances, ruining the country and corrupting the morals of the society. The text argues that the interdiction of the aforesaid fabrics and ornaments was necessary on the grounds of their precarious nature: brought from far off and purchased with extraordinary financial efforts, these clothes were kept in conditions where they deteriorated quickly, damaged by the "smoke" in boyar houses or eaten by moths during the long winters. ${ }^{71}$ The clothes therefore could not accumulate wealth or become a secure capital for the family estate or form part of the inheritance, which was critical for the family's survival. If the boyars wanted adornments,

spătar [minister of the army], grand vistier [treasurer], and grand ban [governor of the province Oltenia]. He authored his history between 1788 and 1794.

69 BAR, Fond Carte rară CRV 443A, ff. 1r-13v. See also Dumitru Furnică: Din istoria comerţului la români mai ales băcănie, 1593-1855. Bucharest 1908, 45-57.

70 Urechia, Istoria românilor, V, 306-307, X/1, 575.

71 Boyar houses were heated in the winter with stoves that produced thick smoke, in rooms that were not well ventilated. Clothes and other items were kept in chests and coffers, sprinkled with tobacco leaves or lavender flowers. 
the text argues, they should adorn themselves with jewelry and other "items of gold", that is, "things that do not spoil" and "are an enduring fortune, which is kept down to the sons of sons". ${ }^{72}$ Indeed, the last wills of contemporaries show that clothes mostly vanished while those other items survived. The will of Maria Văcărescu, for instance, the divorced wife of grand ban Nicolae Brâncoveanu, notes that many of the "fabrics" she had received as dowry have been "lost", while a considerable amount of her jewelry passed to her heirs. Unlike clothing, such items of gold, diamonds, rubies, sapphires, or emeralds could indeed be used as currency to purchase estates, deposited as security, or offered as gifts. ${ }^{73}$

Still, "prestige expenses" (Norbert Elias) were indispensable for maintaining rank, ${ }^{74}$ and the 1778 law explicitly recognized the need for luxury in highlighting and displaying rank, office, and social status in public. It distinguished between the adequate consumption habits of different groups and of individuals of different financial means within these groups. It targeted the "new men", those rich merchants who bought themselves a place in the social hierarchy by the display of opulent luxury, and it acknowledged that the boyars generally believed they were "doing their duty" when they "adorn[ed] themselves with valuable and expensive clothes" and ruined themselves in "glittering ornaments" out of "the love of honor" ${ }^{75}$ Therefore, the text argues, such extravagant expenses should be incurred only by those who can afford them; "those who are lacking and do not have are not obliged to become indebted beyond what is permissible for clothes, which it would be fitting for them to have in common with those of their own sort."76

It is uncertain to what extent these sumptuary laws were followed or enforced. This is a typical problem in the study of legal texts, which has been discussed with regard to other regions. ${ }^{77}$ Prince Constantine Mourouzis' sumptuary law of 1778 apparently was immediately made light of. After the text was read aloud to the public in the main square, to the sound of drums, pamphlets spread in the alleyways of Iaşi mocking the ruler's efforts:

72 BAR, Fond Carte rară CRV 443A, ff. 12v-13r.

73 BAR, Fond Documente Istorice, MLXXXVI/34, 19 September 1797.

74 Norbert Elias: La société de cour. Paris 1974, 49.

75 BAR, Fond Carte rară CRV 443A, f. $7 \mathrm{r}-\mathrm{v}$.

76 BAR, Fond Carte rară CRV 443A, f. 7r.

77 On the Ottoman Empire see Zilfi, Whose laws?, 127. On contemporary Italy see Diane Owen Hughes: Sumptuary Law and Social Relations in Renaissance Italy, in: John Bossy (ed.): Disputes and Settlements. Law and Human Relations in the West. Cambridge 1983, 69-99. 
Contantine Vodă Mourouzis / Being a very grumpy man / Gave an order firmly / That all should wear homespun / Oh, my poor cübbe / With artaname ${ }^{78}$ and heavy / I had lined it with sable fur / To wear it at Christmas / But now woe is me / I'll never put it on again. ${ }^{79}$

Indeed, it seems as if the law could not temper the boyars' desire for social recognition. They seem to have continued playing out their prestige on the public stage through luxury consumption. The sanctioned textiles and ornaments appear prominently among the purchases of members of the boyar elite of the time. For instance, in the same year the law was promulgated, 1778, several such items appear in the dowry received by Măriuţa Cantacuzino-Deleanu, the daughter of the great boyar and former Grand Spătar Iordache Cantacuzino, on her marriage to the former Grand Agă Constantine Ghica: "a cübbe coat of altân [felt cloth with gold thread], a dress, and an anteri coat, all of them similarly furred: with a lining and edging of sable and with heavy laces." The dowry list includes also other items of clothing as well as many other "items of gold". The wedding itself was held with great pomp at the country house of Deleni, outside of Iaşi. ${ }^{80}$

\section{Conclusion}

When in 1711 Phanariot Greeks from Istanbul replaced the local boyars as rulers of Moldavia and Wallachia, this accelerated the process of the Ottomanization of Romanian society, a process that found expression in the clothing and consumption patterns of the local elites. The great boyars with access to the court partly adopted the dress and lifestyle introduced by the new rulers and their entourage. In particular, they started wearing certain Ottoman-inspired headgear, such as the isslic, while their wives admired shawls. Elite members of both sexes also invested heavily in expensive textiles, furs, and other luxury items in accordance with the Phanariots' model. However, the local elites did not simply copy Ottoman clothing items but also found inspiration in European fashion trends. They used these new textiles, garments, and accessories purposefully, in order to fashion their own identity and assert what they saw as their superiority over both the Phanariots and their Greek entourage.

78 Probably altâl, altânbaş, a felt cloth woven with gold thread. See the explanation in Alexianu, Modă şi veşminte, vol. 2, 370.

79 Ibid., 103.

80 BAR, Fond Documente Istorice, CCCCXXVII/53, 2 April 1782. 
Moreover, expensive Ottoman-style clothes and luxury items also served for the boyars as key instruments in the competition for high office and rank among themselves and for the newly rich in their efforts to acquire high office and enter such elite circles. Obtaining and maintaining high social status involved a considerable consumption and public display of luxury goods. To show his rank, a high-ranking boyar had to appear at the princely court in specific attire: a sable islic accompanying a lavishly decorated cübbe with sable lining and a cashmere taklid. He was forced to spend great sums of money or even to go into debt in order to purchase those items that guaranteed him political visibility and a prestigious position in the social hierarchy. Indeed, Ottoman material culture had a profound impact on identity formation in the Danubian Principalities, as it did for Christian elites elsewhere in the Ottoman Empire; it provided social markers of difference and was of utmost importance for the elite's self-representation and self-fashioning.

Consumption, luxury, and the construction of social identity were intrinsically linked, and this applied to both men and women. The wives of the great boyars followed Ottoman fashion trends no less than their husbands, and participated with them in the public display of luxury items. The Romanian sumptuary laws, which were issued by the Phanariot rulers in collaboration with the religious authorities between 1778 and 1815, therefore almost never referred to women as a separate social category. ${ }^{81}$ Rather, they addressed the whole society, singling out men in the upper elite of society for promoting extravagant expenses. However, it seems that expensive clothes and luxury items remained a key means of social distinction. The fragile balance of power made most of the Phanariot rulers hesitant to curb the luxury and ostentation of the local elite by issuing or rigidly imposing clothing laws. Instead, some of them decided to provide a model of modesty themselves, putting pressure on the great boyars to follow suit.

81 Compare the clothing regulations in the Ottoman Empire referring to women, seen as important figures in the propagation of luxury and immorality, Zilfi, Whose laws?, 135-136. 